\title{
Safety Net, Social Protection, and Sustainable Poverty Reduction: A Review of the Evidences and Arguments for Developing Countries
}

\author{
Md. Shahnewaz Khan ${ }^{1}$, Tareq Muhammad Shamsul Arefin ${ }^{2}$ \\ ${ }^{1}$ Assistant Professor, Department of Economics, Jatiya Kabi Kazi Nazrul Islam University \\ Trishal, Mymensingh, Bangladesh \\ ${ }^{2}$ Assistant Professor,Department of Economics, Jagannath University, Dhaka, Bangladesh
}

\begin{abstract}
Since the publication of the World Development Report 1990, diverse views have been forwarded by different institutions and agencies about the role of social protection programs in addressing persistent poverty in the developing countries. This paper reviews the existing evidences and arguments about the impacts of such programs in the developing countries. Most of the literatures have recognized the positive impact of such programs especially on poverty and inequality, school enrollment and drop-out, and better nutrition and health outcomes. However, a major concern about these programs is related to the sustainability of their impacts, i.e., the impacts on growth and long term living standards. While the linkages between social protection and growth in the developed countries have focused cross-country empirical evidences, another view holds that such an approach is unsuitable for the developing countries given the lack of reliable data. With regard to the role of these programs in raising long term living standards, the existing evidences are mixed - some studies have recognized their role while there are skeptical views also. So as to address the structural cause of poverty, few studies have attempted to follow an anti-poverty policy bifurcation, with social protection focusing on transient and asset transfer on chronic poverty. However, the feasibility of policy bifurcation has been challenged also, and as such it has been suggested to map out a broader social protection framework that would take into account factors beyond risk and vulnerability to address both chronic and transient poverty.

Keywords: chronic poverty, growth, investment, social protection, social safety net, transient poverty.
\end{abstract}

\section{Introduction}

The concept of social safety net is not a new one and some form of social security was suggested by the early political economists like Adam Smith, Condorect, and Turgot (Devereux 2002) [1]. Public works schemes for famine relief had been also found in ancient times (Kanbur 2008) [2]. Such programs constituted a major part of the New Deal policies in the USA in 1930s to curb unemployment and tackle the Great Depression. The right to social protection is recognized in the Universal Declaration of Human Rights of 1948 also, as article 22 mentions, "Everyone, as a member of society, has a right to social security and is entitled to realisation through national effort and international co-operation and in accordance with the organisation and resources of each State, of the economic, social and cultural rights indispensable for his dignity and the free development of his personality."

The World Bank's involvement in social protection begun with work on labour markets in the 1970s and the incorporation of safety nets in the structural adjustment programs in 1980s (World Bank 2001) [3]. In the backdrop of debt and economic crisis of the 1980s, the Bank published the World Development Report 1990 (World Bank 1990) [4] which advocated transfers and safety nets as the third prong of the "new poverty agenda". The view on social protection was furthered broadened in the Bank's World Development Report 1995 (World Bank 1995) [5]. The events of the 1990s including the global financial crisis resulted in the implementation of large scale social protection measures with the Bank's assistance. As Kanbur (2008) [2] noted, "From the point of view of poverty, however, the crises of the mid-1990s brought to the fore like never before the issue of safety nets and cast it in a newer, sharper, light......the macroeconomic crises, together with possible negative effects on some poor of policy reform, led in the 1990s to a revisiting of transfer schemes as response to crisis." Given this background, the objective of this paper is to review and summarize the existing evidences and arguments on the role of safety net and protection programs on sustainable poverty reduction in the developing countries. 


\section{Social Safety Net and Social Protection: Concepts and Definitions}

Diverse views and opinions have been forwarded by different institutions and agencies, with regard to the definition and scope of the social safety nets and social protection measures and these views have been often extended and refined, even within institutions. The World Development Report 1990 defined "safety nets" as "some form of income insurance to help people through short term stress and calamities" (World Bank 1990) [4]. The Bank, however, extended its own definition of safety net over time that goes beyond merely addressing the transient poverty thus including interventions against "chronic" as well as "transient" poverty - "safety nets are programs which protect a person or household against two adverse outcomes in welfare: chronic incapacity to work and earn (chronic poverty); and a decline in this capacity from a marginal situation that provides minimal livelihood for survival with few reserves (transient poverty)" (Subbarao, et al. 1996) [6], (Devereux 2002) [1].

Another related concept is "social protection". However, social protection can be seen as a broader concept than safety net. The World Bank (1997) [7] categorized social protection into social insurance program aimed to "support people who are outside the wage economy for some part of their lives" (unemployment benefits, pension, etc), and social assistance program aimed to "help the poorest in society those who are barely able to support themselves" (World Bank 1997 [7], Devereux 2002) [1]. The World Bank's Social Protection Sector Strategy defined social protection in a Social Risk Management (SRM) framework adding macroeconomic stability and financial market development to typical social protection programs whereby SRM is conceived as, "public interventions to assist individuals, households, and communities better management risks and to provide support to the critically poor" (Holzman and Jorgensen 2000) [8], Barrientos, et al. 2005) [9].

The Development Assistance Committee (DAC) Guidelines on Poverty Reduction (OECD 2001) [10] described social protection as "those public actions that enhance the capacity of poor people to participate in, contribute to and benefit from economic, social and political life of their communities and societies". The Department for International Development (DFID) defined social protection as "a subset of public actions, carried out by the state or privately, that address risk, vulnerability and chronic poverty" (DFID 2005) [11].

The Asian Development Bank defined social protection as, "the set of policies and programs designed to reduce poverty and vulnerability by promoting efficient labour markets, diminishing people's exposure to risks, and enhancing their capacity to protect themselves against hazards and the interruption/loss of income" (Baulch, et al. 2008 ) [12].

However, The United Nations Economic and Social Council stated that social protection should be "broadly understood as a set of public and private policies and programmes undertaken by societies in response to various contingencies in order to offset the absence or substantial reduction of income from work; provide assistance to families with children; and provide people with health care and housing" (United Nations 2000) [13], (Barrientos et al. 2005) [9].

According to the ILO definition, social protection should be viewed as, "the set of public measures that a society provides for its members to protect them against economic and social distress that would be caused by the absence or a substantial reduction of income from work as a result of various contingencies (sickness, maternity, employment injury, unemployment, invalidity, old age, and death of the breadwinner); the provision of health care; and, the provision of benefits for families with children" (ILO 2000) [14].

\section{Classification of Safety Net and Protection Programs}

The major safety net and protection programs in the developing countries may be classified into several categories, each having its own advantages and drawbacks and different degrees of relevance and appropriateness depending on the particular socio-economic or country context under which it is implemented (See detail in Michelle, et al. 2004) [15].

a. Cash Transfers and Conditional Transfers: Cash transfer and conditional transfer programs involve the direct transfer of cash to poor households and are often targeted to specific groups - the elderly, children, the malnourished, pregnant women, single parents, the disabled, or the very poor. Such programs are typical in African and Latin American countries. Mexico's Oportunidades(PROGRESA) and Brazil's Bolsa Familia are good examples of conditional cash transfer programs.

b. Free Food Distribution: Free food from food surplus countries is often available to food-deficit countries as food aid. In a pure relief program, food is distributed free, either as disaster relief or as an in-kind transfer to certain disadvantaged groups in the society. Direct distribution is sometimes combined with other programs involving nutrition, education, and health services. The Vulnerable Group Development (VGD) Program in Bangladesh is one of the world's largest food-based intervention programs. 
c. Direct Feeding Programs: Direct feeding programs distribute meals and nutritional supplements to people who are especially vulnerable to malnutrition, usually preschool children and women of childbearing age from low-income households.

d. School-Based Food Programs: School feeding programs distribute prepared food like hot meals, nutrientfortified biscuits, milk, etc to children in school. Food-for education programs distribute free food grain to lowincome families if their children attend primary school; the grain can be used to feed all family members or be sold to meet other expenses.

e. Food Stamps: Food stamps or coupons are distributed to eligible consumers, which have a cash value when used for purchasing food in a commercial store.

f. Price Subsidies: Some form of price subsidies for consumers is common in most developing countries. As a way of protecting the poor from high prices, governments provide food at a lower-than market price; subsidize commodities and services such as electricity, piped water supply, and bus and train fares; provide low-rent housing; and reduce or waive fees for education and health care services.

g. Subsidized Agricultural Inputs: Agricultural inputs such as fertilizers are often subsidized to help poor farmers and increase crop productivity.

h. Public Works Programs: Public works constitute an important type of safety net program for reaching the poor. They provide emergency relief as well as contribute to economic development. These kinds of programs transfer short-term wages or food, but if carefully designed they can also build needed assets such as schools, clinics, and water supply and irrigation networks; facilitate access to markets through the construction of roads and market stalls; and provide training and organizational capacity.

i. Social Health Insurance: In many African countries, social health insurance is a form of social protection. Social health insurance schemes are typically contributory, with participation by government, the beneficiaries themselves, and donor organizations or international agencies such as the International Labour Organisation (ILO).

j. Microfinance: Microfinance, which includes both credit and savings, is a form of social protection and enterprise promotion. The worldwide microfinance movement has promoted individual and group-based access to savings and credit, sometimes with insurance and training components.

\section{Impact of Social Protection Programs in Developing Countries}

There is a wide range of literatures showing the positive impacts of safety nets and protection on the incidence of poverty and the extent of inequality; school enrollment; nutrition and energy consumption; participation in labour markets; and income, investment and savings, etc (Summary findings on the impacts of these programs are available in Barrientos 2008 [16], and IFPRI 2002 [17]) . Skoufias (2001) [18] estimated that the PROGRESA interventions in Mexico reduced the number of people with income levels below the poverty level by about 10 percent. The depth of poverty was reduced by 30 percent, and the severity index was reduced by 45 percent. The impact of such programs upon inequality-reduction is evident in an estimate by Soares, et al. (2007) [19]. The estimate shows that Brazil's Bolsa Familia and Mexico's Opportunidades (PROGRESA) each had contributed to 21 percent of the reduction of Gini-indices of these countries while Chilean Solidario had contributed to 15 percent of the reduction of the index, between 1995 and 2004.

A study by Schulz (2000) [20] found that at the primary level, where enrollment before PROGRESA had been already between 90 and 94 percent, the program succeeded at increasing the enrollment of boys up to 1.07 percent and of girls up to 1.45 percent. At the secondary level with initial enrollment rates before PROGRESA being 67 percent for girls and 73 percent for boys, the increase in enrollment for girls ranged from 7.2 to 9.3 percentage points and for boys from 3.5 to 5.8 percentage points. If the positive program effects could be sustained, the study suggested, the program would increase educational attainment of the poor of both sexes by 0.66 years of additional schooling (Schulz 2000) [20]. Another study by Behrman, et al. (2000) [21] suggested that the PROGRESA intervention was especially effective in reducing drop-out rates during transition from primary to secondary school. The study by Ahmed and Ninno (2002) [22] suggested that the Food for Education (FFE) program in Bangladesh was successful in increasing primary school enrollment, promoting school attendance and reducing drop-out rates. Furthermore, the study suggested that the increase in enrollment was greater for girls than for boys. 
Study findings also revealed that PROGRESA had a significant impact on increasing child growth and in reducing the probability of stunting for children aged 12-36 months (Behrman and Hoddinott 2000) [23]. Gertler (2000) [24] found 12 percent lower incidence of illness among PROGRESA children (aged 0-5 years) as compared to non- PROGRESA children. In addition, the study also found the adult members in beneficiary households being significantly healthier than non-beneficiary households. In the case of Bolivia's BONSOL program, Martinez (2004) [25] found that the beneficiary households had experienced increased food consumption by 6.3 percent, and that those in rural areas had experienced an average increase in food consumption of 165 percent of the transfer value, through use of the transfer for investment in agricultural productivity. For another program in Bangladesh, Haseen (2007) [26] found that the eligible households had significantly improved consumption of a range of food groups.

Chirwa, et al. (2004) [27] found that a significant number of beneficiaries of the "Improving Livelihood through Public Works Program" in Malawi had spent money on farm inputs and that the infrastructure built by the project had opened new business opportunities and improved communication. Devereux (2001) [28] estimated that 34 percent of the benefit-recipients of the "Social Pension" scheme of Namibia used part of the transfer in saving. Parker and Skoufias (2000) [29] found the changing patterns of decision-making within beneficiary households of PROGRESA. In another program in South Africa, McCord (2004) [30] noted that the Public Works Pension had the likelihood of increasing labour force participation.

\section{Social Protection and Growth: Developing Country Perspectives}

Although there are a large number of literatures on the impact of social protection programs on reduction of poverty and vulnerability in the developing countries, little attention has been paid on their impacts upon growth, which is mainly due to the fact that promotion of growth has rarely been the explicit objective of such programs in these countries. It is widely believed that protection programs have negative effects on growth, particularly in the developed countries. Such effects are expected to arise due to the negative impact of these programs on incentives to work and saving among the beneficiaries. However, no empirical clear-cut conclusion has been established to date in favour of such arguments (Barrientos 2008) [16].

While the linkages between transfers and growth in the developed countries focused on cross-country empirical studies testing the hypothesis of a correlation across a sample of countries, Barrientos (2008) [16] have argued that such an approach is unsuitable for examining the impacts in the developing countries, given the lack of reliable data for many developing countries. It is argued by Barrientos (2008) [16] that those who are in poverty face a different sets of constraints and opportunities than those rich, and so it is important to highlight the particular circumstances of the poor so as to identify the growth effects of the safety net programs in the developing countries. Thus Barrientos (2008) [16] has suggested a basic framework for tracing the growth effects of social transfer programs and identified three processes through which these programs can lead to investment and growth at the household level -

First, the extent to which social transfers is able to lift credit constraints: Credit markets usually exclude the poor and the poorest. Regular and reliable transfers can help overcoming the barriers in the access to credit. Examples include the case of "Previdencia Rural" of Brazil (Scwarzer 2000 [31] in Barrientos 2008 [16]) and "Targetting the Ultra Poor" program in Bangladesh (Rabbani, et al. 2006 [32] in Barrientos 2008 [16]).

Second, the extent to which social transfers can provide greater certainty and security in consumption and investment outcomes: Insurance market seldom reaches poor households so that they remain insufficiently protected (Jalan and Ravallion 1999 [33], Dercon 2005 [34] in Barrientos 2008 [16]). Insecurity leads to inefficient use of resources (Barrientos 2007 [35] in Barrientos 2008 [16]) by the poor households to undertake low risk-low/low-return crops and production methods (Morduch 1995 [36] in Barrientos 2008 [16]) which reduces growth opportunities. Insecurity also forces poor households to holding liquid but less productive assets (Dercon 2003) [37] in Barrientos 2008 [16]). Social transfers can provide increased security and in the process make investment possible. For example, the Employment Guarantee Scheme in Maharasthra India enabled farmers to plant high yield crops, rather than the low-yield, drought-resilient varieties used elsewhere (Devereux 2002) [1], (Barrientos 2008) [16].

Third, the extent to which social transfers facilitate improved household resource allocation and dynamics: Household resource allocation can be less than optimal if poverty related credit and liquidity constraints prevent resource reallocation. Social transfer can help overcome investment restrictions arising from intra-household dynamics. It is often the result that transfers may cause a shift in consumption towards children related goods and services, as in PROGRESA-Mexico (Rubalcava, et al. 2002 [38] in Barrientos 2008 [16]). 
Therefore, as suggested by Barrientos (2008) [16], the effectiveness of social transfer programs can be measured with regard to outcomes on four variables: First, human capital development: It is realized through improvement in school attendance or utilization of primary health care (such programs are quite common in Mexico and Bangladesh). Second, asset accumulation: In low and middle income countries, few studies indicate that an important portion of beneficiary households save a small fraction of the transfer. Third, labour supply: while standard economics suggest a decline in the labour supply among beneficiary households as a result of the transfer, this is not matched by realities in the developing countries. Some robust findings suggest that an increase in unearned income, which leads to a reduction of labour supply of children and older people, is often compensated by increase in the labour supply by other household members (Skoufias 2001) [18]. Fourth, local economy-effects: Public works programme transfers income to households and thus boost local trade by stimulating effective demand, and also at the same time can improve the local infrastructure (Barrientos and Sabates-Wheeler 2007) [39].

\section{Can Social Protection Answer Sustained Poverty Reduction?}

There are other literatures which sought to answer question on the role of social protection programs on sustainable poverty reduction, i.e., their effects on redressing chronic poverty and thus improving the long term living standards of the beneficiaries. By examining three safety net programs in South Africa Devereux (2002) [1] argued that the social safety nets can reduce chronic poverty through two mechanisms - (a) asset creation by the project and (b) investment behaviour by the project participants. First, Social safety nets can contribute to capital formation (asset creation) in a number of ways - (i) by improving the nutritional standards of the beneficiaries thus contributing to improving their labour productivity; (ii) by building human capital through investing in education (several studies found positive correlation between school feeding programs and school participation of children); and (iii) most of the social safety nets programs in the poor countries are in the form of public works project and transfer food and income in the short run and create permanent assets that have sustainable impacts on poverty reduction. Public work program has indirect effects also - income stabilization, multiplier, and insurance effects. Food /cash wages paid to workers may stabilize their income (or consumption) after poor harvests (stabilization effect); those may boost workers purchasing power and thus boost up the local economy (multiplier effect); and if they are confident that the works will be available to them, they may invest incomes to business or agriculture, which could otherwise be kept as precautionary savings (insurance effect). Second, empirical evidence suggests that safety nets may encourage moderate risk taking behavour by the beneficiaries like investment in agriculture or petty trading (as in the case of Employment Guarantee Scheme in Maharasthra, India). Thus safety nets may have effects not only on livelihood-protection but also on livelihoodpromotion. It suggests that social safety nets, far from being a residual welfarist-intervention to alleviate transitory and livelihood shocks, can play a significant role in reducing chronic poverty (Devereux 2002) [1].

By estimating the impact of Rural Mexico's OPORTUNIDADES program, Gartler, et al. (2006) [40] suggested that transfers from the program resulted in increased investment in micro-enterprise and agricultural activities among the benefit recipients. The study found that for each peso transferred, beneficiary households used 88 cents to purchase consumption goods and services, and invested the rest. The study estimated that the investments improved the household's ability to generate income with a rate of return of 17.6 percent. It also estimated that the beneficiary households were able to increase their consumption by 34 percent after five and a half years in the program by investing transfers to raise income. Thus the study provided evidence that cash transfer program can increase consumption not only through direct expenditures out of current transfers, but also through income generated from investing part of the transfers in farm and micro-enterprises. Gartler et al. (2006) [40] argued that cash transfers to the poor may raise their long-term living standards, which are maintained after program benefits end. According to them, there are two primary pathways by which transfers correct market failures that limit investment in productive activities in the developing countries: First, transfers alleviate liquidity and credit constraints that contribute to poverty traps, whereby poor households are able to afford the startup costs associated with entrepreneurial activities; and Second, if transfers are perceived as a secured source of income, risk-adverse households will be more willing to increase ownership of risky assets, even in the presence of risk (Gertler et al. 2006) [40].

However, there are also literatures which raised questions about the role of traditional transfer programs in tackling the chronic poverty. Such literature attempts to decompose poverty into "chronic" and "transient" categories and defines "chronic" poverty as a factor of "insufficient welfare generating assets" as distinct from "transient" poverty understood as a factor of the "variability in the returns from these assets" (Barrientos et al. 2005) [9], (Jalan and Ravallion 2001) [41]. By examining the distinction between "transient" and "chronic" poverty in the context of rural China, Jalan and Ravallion (2001) [41] suggested a bifurcation in anti-poverty policy. Such an anti poverty policy-bifurcation implies that different types of policies should be followed to tackle the two types of poverty - "social protection" measures should focus on transient poverty whilst an "asset building" approach be followed to address chronic poverty. However, the grounds for such a 
bifurcation in the anti-poverty measures are contested by Barrientos et al. (2005) [9]. According to them, the transient poor and chronically poor are not always distinguished "crisp" categories and they have some common causal factors also. They have pointed out that risk and vulnerability are important factors in shaping chronic poverty also and so the social protection programs can have important role in reducing and preventing chronic poverty. However, they have suggested for taking into account the structural factors beyond risk and vulnerability to address the persistent poverty. Thus Barrientos et al (2005) [9] have called for a "broader vision" for social protection which would focus on both short and long term interventions protecting not only the consumption of individuals and households but also their investment and asset accumulation. They have also suggested for mapping out such a broader social protection framework for developing countries which can tackle both chronic and transient poverty.

\section{Summary and Conclusion}

The positive impacts of social safety net and social protection programs in the developing countries are quite evident in terms of reducing poverty and inequality, increasing enrollment at primary and secondary levels, promoting school attendance, reducing drop-out rates, and increasing educational attainment. Such programs have also impacts on increasing child growth, lowering incidence of illness among children and having better health outcomes in the beneficiary households.

It is widely believed that social transfer programs have negative impacts on growth particularly in developed countries, due to their negative impacts on incentives to work and saving among beneficiaries. However, there is no empirical clear-cut evidence in favour of such arguments. While the linkages between social transfers and growth in the developed countries focused cross-country empirical studies, it is also argued in the literature that such an approach is unsuitable in the case of developing countries, due to lack of reliable data. It has been argued that the poor in the developing countries face a different set of constraints and opportunities, for which it is important to highlight their particular circumstances to identify the growth effects of such programs on them. It is suggested that the growth effects of such programs on the poor of developing countries can be measured with regard to their outcomes on human capital development, asset accumulation, labour supply, and local economy.

Evidences are available in favour of the argument that protection programs have positive impacts on raising the long term living standards of the beneficiaries. Such evidences highlight the role of these programs to creating assets and encouraging investment among the project participants. However, skeptical views are also available in the existing literatures. One approach has attempted to make a distinction between transient and chronic poverty and have called for making a policy-bifurcation with social protection addressing transient and asset transfer addressing chronic poverty. However, there is also argument that these two types of poor have some common causal factors of their being poor and so it is not feasible to make policy bifurcation. As such it has been suggested to map out a broader social protection framework taking into account of the factors beyond risk and vulnerability and protect not only consumption but also investment and asset accumulation to address both transient and chronic poverty.

\section{References}

[1] Devereux, S. (2002). Can Social Safety Nets Reduce Chronic Poverty?, Development Policy Review, 20 (5):657-675.

[2] Kanbur, R. (2008). Poverty and Distribution: Twenty Years Ago and Now. Working Paper. Cornell University, Department of Applied Economics and Management.

[3] World Bank (2001). Social Protection Sector Strategy: From Safety Net to Springboard. The World Bank Group, The Human Development Network, The World Bank, Washington, D.C.

[4] World Bank (1990). World Development Report 1990. Washington, DC: Oxford University Press for the World Bank.

[5] World Bank (1995). World Development Report 1995. Washington, DC: Oxford University Press for the World Bank.

[6] Subbarao, K., A. Bonnerjee, J. Braithwaite, S. Carvalho, K. Ezemenari, C. Graham, and A. Thomson (1996). Social Assistance and Poverty-Targeted Programs. Washington, DC: World Bank Poverty and Social Policy Department.

[7] World Bank (1997). World Development Report 1997. Washington, DC: Oxford University Press for the World Bank.

[8] Holzman, R. and S. Jorgensen (2000). Social Protection Sector Strategy Paper: From Safety Net to Trampoline .Washington, DC: World Bank.

[9] Barrientos, A., D. Hulme, and A. Shepherd (2005). Chronic Poverty and Social Protection: Can Social Protection Tackle Chronic Poverty?, European Journal of Development Research, March 2005.

[10] OECD (2001). Poverty Reduction, DAC Guidelines and Reference Series, OECD, Paris.

[11] DFID (2005). Social Transfers and Chronic Poverty: Emerging Evidence and the Challenges Ahead. A Department for International Development (DFID) Practice Paper.

[12] Baulch, B., A. Weber and J. Wood (2008). Social Protection Index for Committed Poverty Reduction. Vol 2: Asia (Manila). Asian Development Bank.

[13] United Nations (2000). Enhancing Social Protection and Reducing Vulnerability in a Globalizing World. Report of the Secretary General to the Thirty-ninth Session E/CN.5/2001/2, Washington, D.C: United Nations Economic and Social Council.

[14] ILO (2000). Wold Labour Report 2000: Income Security and Social Protection in a Changing World. London, International Labour Office. 
[15] Michelle, A., A. Ahmed, and F. Lund (2004). Linking Safety Nets, Social Protection, and Poverty Reduction - Directions for Africa. Brief prepared for the conference on Assuring Food and Nutrition Security in Africa by 2020: Prioritizing Actions, Strengthening Actors, and Facilitating Partnerships, held in Kampala, Uganda, April - 2004.

[16] Barrientos, A. (2008). Social Transfers and Growth: A Review. Working Paper (no. 112), Chronic Poverty Research Centre (CPRC).

[17] IFPRI (2002).PROGRESA: Breaking the Cycle of Poverty. International Food Policy Research Institute, Washington DC.

[18] Skoufias, E. (2001). Progresa and Its Impact on the Human Capital and Welfare of Households in Rural Mexico: A Synthesis of the Results of an Evaluation by International Food Policy Research Institute. IFPRI Report, Washington DC.

[19] Soares, S., R. G. Osorio, F. V. Soares, M. Medeiros, and E. Zepeda (2007). Conditional Cash Transfers in Brazil, Chile and Mexico: Impacts upon Inequality. Working Paper, International Poverty Centre.

[20] Schultz, T. P. (2000). Final Report: The Impact of PROGRESA on School Enrollments. International Food Policy Research Institute, Washington, D.C.

[21] Behrman, J., P. Sengupta, and P. Todd (2000). The Impact of PROGRESA on Achievement Test Scores in the First Year. International Food Policy Research Institute (IFPRI).

[22] Ahmed, A. U. and C. Ninno (2002). Food for Education Programme in Bangladesh: An Evaluation of the Impact on Educational Attainment and Food Security. International Food Policy Research Institute Discussion Paper 138. Washington DC: International Food Policy Research Institute.

[23] Behrman, J. R. and J. Hoddinott (2000). An Evaluation of the Impact of PROGRESA on Pre-School Child Height. Washington, DC: International Food Policy Research Institute (IFPRI).

[24] Gertler, P. (2000). Final Report: The Impact of PROGRESA on Health. Washington, DC: International Food Policy Research Institute: IFPRI.

[25] Martinez, S. (2004). Pensions, Poverty and Household Investments in Bolivia. Mimeo. Berkeley: University of California at Berkeley.

[26] Haseen, F.(2007). Change in Food and Energy Consumption among the Ultra Poor: Is the Poverty Reduction Programme Making a Difference?, Asia Pacific Journal of Clinical Nutrition, 16, 58-64.

[27] Chirwa, E. W., P. M. Mvula, and B. M. Dulani (2004). The Evaluation of the Improving Livelihoods Through Public Works Programme. Lilongwe, Malawi: Improving Livelihoods Through Public Works Programme (ILTPWP).

[28] Devereux, S. (2001). Social Pensions in Namibia and South Africa. Institute of Development Studies Discussion Paper. Brighton, UK: Institute of Development Studies (IDS).

[29] Parker, S. and E. Skoufias (2000). The Impact of PROGRESA on Work, Leisure, and Time Allocation. International Food Policy Research Institute, Washington, D.C.

[30] McCord, A. (2004). Policy Expectations and Programme Reality: The Poverty Reduction and Labour Market Impact of Two Public Works Programmes in South Africa. ESAU Working Paper. London: Overseas Development Institute.

[31] Schwarzer, H. (2000). Impactos Socioeconomicos do sistema de aposentadorias rurais no Brazil - Evidencias Empiricus de un Estudio de Caso no Estado de Para”, Discussion Paper 729, Rio de Janerio: Institute de Pesquisa Economica Aplicada (IPEA).

[32] Rabbani, M., V. A. Prakash, and M. Sulaiman (2006). Impact Assessment of CFPR/TUP: A Descriptive Analysis Based on 20022005 Panel Data. Working Paper 12. Dhaka: BRAC Centre.

[33] Jalan, J. and M. Ravallion (1999). Are the Poor Less Well Insured? Evidence on Vulnerability to Income Risk in Rural China. Journal of Development Economics, 58, 61-81.

[34] Dercon, S (Ed.) (2005). Insurance Against Poverty: Oxford, Oxford University Press.

[35] Barrientos, A. (2007). Does Vulnerability Create Poverty Traps? Chronic Poverty Working Paper. Manchester, UK: Institute for Development Policy and Management/ Chronic Poverty Research Centre (CPRC).

[36] Morduch, J. (1995). Income Smoothing and Consumption Smoothing, Journal of Economic Perspectives, 9, (3), 103-114.

[37] Dercon, S. (2005). Risk and Poverty: A Selective Review. Mimeo. Oxford: Department of Economics, Oxford University.

[38] Rubalcava, L., G. Teruel, and D. Thomas (2002). Welfare Design, Women's Empowerment and Income Pooling. Mimeo. Centro de Investigecion y Docencia Economics.

[39] Barrientos, A. and R. Sabates-Wheeler (2007). Local Economy Effects of Social Transfers. Mimeo, Brighton: Institute of Development Studies.

[40] Gertler, P., S. Mertinez, and M. Rubio-Codina (2006). Investing Cash Transfers to Raise Long-Term Living Standards. World Bank Policy Research Working Paper 3994, August 2006.

[41] Jalan, J. and M. Ravallion (2001). Is Transient Poverty Different? Evidence for Rural China. Journal of Development Studies, Vol 36, No 6 . 